\title{
Antiparasitic antibodies occur with similar frequency in patients with clinically established multiple sclerosis with or without oligoclonal bands in the cerebrospinal fluid
}

Anticorpos antiparasitários ocorrem com frequência semelhante em pacientes com esclerose múltipla quando há e quando não há bandas oligoclonais no líquido cefalorraquidiano

Fabiana Cruz Gomes da Fonseca-Papavero', Dagoberto Callegaro², Paulo Diniz da Gama², José Antonio

Livramento', Adelaide José Vaz ${ }^{4}$, Luís dos Ramos Machado ${ }^{5}$

\begin{abstract}
The "hygiene hypothesis" postulates an inverse relationship between the prevalence of parasitic infections and the frequency of multiple sclerosis (MS). Objective: It was to study whether antibodies against parasites could be demonstrated more frequently in blood serum from MS patients with oligoclonal bands (OCB) than from MS patients without OCB. Methods: We studied serum samples from 164 patients who had previously been analyzed to investigate OCB. Parasitic antibodies were studied through unidimensional electrophoresis of proteins on polyacrylamide gel against Taenia antigens, searching for antiparasitic specific low molecular weight antibodies and also for antiparasitic nonspecific high molecular weight antibodies. Results: Two of the 103 patients with no evidence of OCB had antibodies of low molecular weight and 59 of them had antibodies of high molecular weight. Of the 61 patients with evidence of OCB, one showed antibodies of low molecular weight and 16 showed antibodies of high molecular weight. Conclusion: Antiparasitic antibodies are detected with similar frequency in MS patients with OCB and in MS patients without OCB.
\end{abstract}

Key words: hygiene hypothesis, multiple sclerosis, oligoclonal bands, Taenia antigens, antiparasitic antibodies.

\section{RESUMO}

A "hipótese da higiene" postula haver relação inversamente proporcional entre a prevalência de infecções por parasitas e a frequência da esclerose múltipla (EM). Objetivo: Foi verificar se em pacientes com EM aparecem anticorpos antiparasitários mais frequentemente no grupo com bandas oligoclonais (BOC) do que no grupo sem BOC. Métodos: Foram estudadas amostras de sangue de 164 pacientes previamente analisadas para investigar BOC. Foi feita eletroforese unidimensional de proteínas em gel de poliacrilamida contra antígenos de Taenia para pesquisa de anticorpos específicos de baixo peso molecular e também de anticorpos inespecíficos de alto peso molecular. Resultados: Dois dos 103 pacientes em que não havia BOC apresentaram anticorpos de baixo peso molecular, e 59 apresentaram anticorpos de alto peso molecular. Dos 61 pacientes em que não havia BOC, um apresentou anticorpos de baixo peso molecular e 16, anticorpos de alto peso molecular. Conclusão: Anticorpos antiparasitários foram detectados com frequência semelhante em doentes com EM independentemente da presença ou não de BOC.

Palavras-Chave: hipótese da higiene, esclerose múltipla, bandas oligoclonais, antígenos de Taenia, anticorpos antiparasitários.

Multiple sclerosis (MS) is a chronic inflammatory immune-mediated and demyelinating disease of the central nervous system (CNS) $)^{1-3}$.

The frequency of MS in Brazil varies among different regions due to ethnic diversity and the diversity of environmental and socioeconomic characteristics due to the country's large territorial extent ${ }^{4-6}$.

A recent study on patients with MS in the city of São Paulo, Brazil, showed that oligoclonal bands (OCB) are present in $54.4 \%$ of patients with MS. This rate is substantially lower than

\footnotetext{
Study carried out at Faculdade de Medicina da Universidade de São Paulo (FM/USP), São Paulo SP, Brazil.

'Laboratório de Investigação Médica em Neurologia (LIM 15) da FM/USP, São Paulo SP, Brazil;

${ }^{2}$ Ambulatório de Doenças Desmielinizantes do Hospital das Cínicas da FM/USP, São Paulo SP, Brazil;

${ }^{3}$ Departamento de Neurologia, Pontifícia Universidade Católica (PUC) de São Paulo, Sorocaba SP, Brazil;

${ }^{4}$ Departamento de Análises Clínicas, Faculdade de Ciências Farmacêuticas, USP, São Paulo SP, Brazil;

${ }^{5}$ Departamento de Neurologia do Hospital das Clinicas da FM/USP, São Paulo SP, Brazil.

Correspondence: Fabiana Cruz Gomes da Fonseca-Papavero;Avenida Dr.Arnaldo 455 / sala 4110;01246-903 São Paulo SP- Brasil; E-mail:fabianacruz@lim15.fm.usp.br

Conflict of interest: There is no conflict of interest to declare.
}

Received 20 March 2013; Received in final form 28 March 2013; Accepted 04 April 2013. 
that described in Caucasian populations of Europe and North America, where OCB are registered in 90 to $95 \%$ of patients with MS. On the other hand, the values observed among patients from the city of São Paulo are similar to those described in other areas, such as China, Japan, Lebanon and India, where OCB are found in 30 to $60 \%$ of patients ${ }^{7}$.

The so-called "hygiene hypothesis" has been receiving attention lately ${ }^{8}$. This is a hypothesis similar to what has already been accepted in the field of studies on phenomena relating to allergic diseases. The core of this theory proposes that, as developing countries improve their socioeconomic conditions, the prevalence of endemic parasitic infestations would decrease and, inversely, the frequency of autoimmune or immune-mediated diseases would increase.

Several studies have shown that helminthic infections decrease the risk of autoimmune and allergic diseases ${ }^{9}$. Correale et al. showed that patients with MS who became infected by helminths had a significant decrease in their relapses, lower disability scores on specific MS scales and lower disease activity, as shown by magnetic resonance (MR), in relation to patients who were not infected ${ }^{10}$.

Among the most frequent parasitic infections in developing countries, the taeniasis-cysticercosis complex must be highlighted. This complex is more widely distributed in developing countries, particularly in Africa, India and Latin America. This parasite is endemic even in some prosperous Brazilian regions, such as the States of Paraná, Minas Gerais, Goiás and São Paulo ${ }^{11}$.

The potential relationship between immune-mediated inflammatory diseases affecting the central nervous system and human infection due to the taeniasis-cysticercosis complex has not been studied yet. The immune-diagnosis of taeniasis has been established using the ORF strain of Taenia crassiceps, which shows very high antigenic identity with Taenia solium. It thus allows routine use of T. crassiceps antigens with absolute safety, as proven by exhaustive compatibility testing ${ }^{12}$. In fact, obtaining Taenia solium antigens from the tissue of infected animals presents difficult-to-control technical problems regarding molecular biology tests.

Using techniques of electrophoresis on acrylamide gel, it is possible, in a large proportion of serum samples, to detect the presence of antibodies that may be specific or nonspecific to taeniasis. Fractions that are smaller than $30 \mathrm{kDa}$ are specific, and those of high molecular weight are described as being nonspecific and directed towards a pool of parasitic antigens ${ }^{13}$. According to Ishida et al. ${ }^{14}$, these fractions larger than $30 \mathrm{kDa}$ occur in cases of toxocariasis, schistosomiasis and hydatidosis, among other parasitic infestations. It is possible that these antigens of high molecular weight have some type of "protective" role in relation to the host.

The objective of the present study was to assess the frequency of antiparasitic antibodies anti-Taenia and high molecular weight nonspecific antiparasitic antibodies in serum from patients with MS, in groups with and without OCB.

\section{METHODS}

The present laboratory study was conducted using surplus serum collected from patients with MS who were living in the city of São Paulo and had undergone investigations regarding the presence of $\mathrm{OCB}^{7}$.

This study was approved by the Ethics Committee for Research Project Analysis in the institution carrying out the work. Since only previously collected samples were used, there was no need for a consent statement signed by the patient.

The inclusion and exclusion criteria for patients in this sample were previously described by Gama et al. ${ }^{7}$.

The sample for this study comprised 164 patients divided into four groups: (a) Group 1 - patients with clinically defined MS - 90 patients, of whom 49 presented OCB (54.4\%); (b) Group 2 - patients who presented the first episode of a demyelinating disease, or clinically isolated syndrome (CIS) 16 patients, of whom five presented OCB (31.3\%); (c) Group 3 - patients with inflammatory neurological diseases (IND) except for neurocysticercosis - 39 patients, of whom 7 presented OCB (17.9\%); (d) Group 4 - control group - patients with no neurological complaints who had undergone small surgeries that required spinal anesthesia - 19 patients, of whom none had OCB.

Reading of the material to identify OCB was carried out by means of a qualitative method, isoletric focusing, and the result was either presence or absence ${ }^{7}$.

Validity tests to assess the sensitivity and specificity of OCB detection method in these patients, as well as descriptive statistics relating to gender, ethnic background and MS presentation, were reported by Gama et al. ${ }^{7}$

The antigenic extracts used for the study were: vesicular fluid from cysticerci of T. solium (LV-Tcra) ${ }^{15}$, and the excretion and secretion fluid from cysticerci of T. crassiceps produced within 180 minutes (ES-Tcra 180) ${ }^{16}$. These were kindly provided by Prof Dr Adelaide José Vaz (in memoriam).

The LV-Tcra and ES-Tcra-180 extracts were separated by means of unidimensional protein electrophoresis on polyacrylamide gel. After electrophoresis, an immunoblot (IB) of the antigens was obtained in accordance with the method describer by Towbin et al. ${ }^{17}$.

All electrophoresis runs included both a positive and a negative control.

\section{RESULTS}

Table shows the results for low and high molecular weight antibodies in the different groups, in the presence or absence of OCB.

In the group of MS patients, those with OCB presented anti-Taenia antibodies at a similar frequency to those without OCB $(p=0.9)$. The same result was obtained for nonspecific antibodies of high molecular weight $(\mathrm{p}=0.3)$. 
This finding was repeated when the group with CIS was studied to detect antiparasitic antibodies in relation to the presence or absence of OCB ( $\mathrm{p}=0.6)$.

Likewise, in the group of inflammatory neurological diseases, there was no significant difference when considering patients with and without OCB in relation to the presence of specific $(p=0.06)$ or nonspecific $(p=0.9)$ antiparasitic antibodies.

\section{DISCUSSION}

The following topics will be discussed: (1) antiparasitic antibodies that are specific for the taeniasis-cysticercosis complex and the presence of OCB; (2) nonspecific antiparasitic antibodies that have high molecular weight and the presence of OCB; (3) the low prevalence of OCB in the group of patients from this sample and the occurrence of antiparasitic antibodies; (4) specific and nonspecific antiparasitic antibodies in patients with multiple sclerosis in relation to patients in the control group.

\section{(1) Antiparasitic antibodies that are specific for the taeniasis-cysticercosis complex and the presence of oligoclonal bands}

Specific antiparasitic antibodies were identified at similar frequencies in serum from patients with MS with and without OCB.

In our study, we considered the possibility that taeniasiscysticercosis could have a role similar to that proposed by the "hygiene hypothesis", since the region from which the patients of this sample came from was endemic for this parasitic infestation and the frequency of MS is lower than that of other populations.

This hypothesis was not confirmed. We can therefore state that the presence of antiparasitic antibodies did not modify the occurrence of OCB in patients with MS.

\section{(2) Nonspecific antiparasitic antibodies and occurrence of oligoclonal bands in patients with multiple sclerosis}

Serum nonspecific antiparasitic antibodies were found in patients with multiple sclerosis with OCB at a similar frequency to that of patients without OCB.
We considered that the taeniasis/cysticercosis complex might be too particular and too specific to have an important role in the "hygiene hypothesis". Therefore, we studied nonspecific antibodies of high molecular weight, which have been correlated with a series of parasites that are prevalent in the population sample. These might have a protective role for the host.

This hypothesis was not confirmed either. The frequency of OCB in patients with multiple sclerosis was not affected by occurrences of nonspecific antiparasitic antibodies.

\section{(3) The low prevalence of oligoclonal bands in the group of patients comprising this sample and the occurrence of antiparasitic antibodies}

The results from the present study showed that it was not possible to attribute the low frequency of OCB in this sample of patients to the presence of antiparasitic antibodies in the serum of these patients.

Therefore, it is likely that the low prevalence of OCB observed in our sample was related to more than one factor, possibly with different degrees of influence on the final result. It is necessary to take into consideration that the region from which the samples came represented the typical profile of a large developing metropolis, with wide variations and inequalities that result from internal and external migrations, and with a high degree of ethnic miscegenation. Thus, it is difficult to consider that a person belongs or does not belong to a certain socioeconomic group without accepting different gradations in each domain, and these cannot always be quantified.

\section{(4) Specific and nonspecific antiparasitic antibodies in patients with multiple sclerosis in relation to patients in the control group}

The set of antiparasitic antibodies, irrespective of specificity, presented similar frequency in patients with multiple sclerosis and controls.

The control group for this study was selected carefully, in order to avoid inclusion of patients with immune-mediated diseases or conditions related to these diagnoses.

Table. Frequency of antiparasitic antibodies of low and of high molecular weight in patients with multiple sclerosis and controls.

\begin{tabular}{|c|c|c|c|c|c|}
\hline \multirow{2}{*}{ Groups } & & \multirow{2}{*}{$\mathrm{n}$} & \multirow{2}{*}{ Antiparasitic Ab } & \multirow{2}{*}{$\begin{array}{c}\text { Low weight } \\
n(\%)\end{array}$} & \multirow{2}{*}{$\begin{array}{c}\text { High weight } \\
n(\%)\end{array}$} \\
\hline & & & & & \\
\hline \multirow{2}{*}{90 patients with MS } & OCB - & 41 & Ab anti-Taenia + & $1(2.4)$ & $13(31.7)$ \\
\hline & $\mathrm{OCB}+$ & 49 & Ab anti-Taenia + & $1(2.0)$ & $11(22.4)$ \\
\hline \multirow{2}{*}{16 patients with CIS } & OCB - & 11 & Ab anti-Taenia + & 0 & $5(45.4)$ \\
\hline & $\mathrm{OCB}+$ & 5 & Ab anti-Taenia + & 0 & $3(60.0)$ \\
\hline \multirow{3}{*}{$\begin{array}{l}39 \text { patients with other inflammatory } \\
\text { neurological diseases } \\
19 \text { patients without neurological } \\
\text { complaints }\end{array}$} & OCB - & 32 & Ab anti-Taenia + & $1(3.1)$ & $10(31.2)$ \\
\hline & $\mathrm{OCB}+$ & 7 & Ab anti-Taenia + & 0 & $2(28.6)$ \\
\hline & OCB - & 19 & Ab anti-Taenia + & 0 & $7(36.8)$ \\
\hline
\end{tabular}

MS: multiple sclerosis; CIS: clinically isolated syndrome; OCB: oligoclonal bands; ab: antibodies. 
Therefore, it is clear that the possible inverse relation between immune-mediated diseases and the frequency of parasitic infestations could not be established in the present study.

Some parasitic infestations may not induce production of antibodies. It is therefore possible that the "hygiene hypothesis" is related to a more restricted group of parasites, in which the diagnosis is not based on detection of antibodies in the serum.

This possibility may have been the reason for the results observed among the patients in this study.
In conclusion, it is possible that the "hygiene hypothesis" does not have a very direct causal role, or at least not such a linear role as has been proposed, with regard to either occurrences of MS or the frequency of OCB among patients with MS.

In response to the thinking of Sotgiu et al. ${ }^{18}$, the "hygiene hypothesis" continues to raise numerous questions that still require investigation regarding: (a) the nature of protective infectious agents; (b) the course of the autoimmune diseases with which they could interact; (c) the impact on patients' immunological balance; and (d) the protective mechanisms that infectious agents themselves can trigger against immune-mediated diseases.

\section{References}

1. Poser CM, McDonald WI. An atlas of multiple sclerosis. Nova York: The Parthenon Publishing Group; 1998.

2. Reiber H. Cerebrospinal fluid - physiology, analysis and interpretation of protein patterns for diagnosis of neurological diseases. Mult Scler 1998;4:99-107.

3. Link H, Huang Y-M. Oligoclonal bands in multiple sclerosis cerebrospinal fluid:an update on methodology and clinical usefulness.J Neuroimmunol 2006;180:17-28.

4. Lana-Peixoto, Frota ERC, Campos GB, et al. The prevalence of multiple sclerosis in Belo Horizonte, Brasil. Arq Neuropsiquiatr 2012;70:102-107.

5. Ribeiro SBF, Maia DF, Ribeiro JB, et al. Clinical and epidemiological profile of patients with multiple sclerosis in Uberaba, Minas Gerais, Brazil. Arq Neuropsiquiatr 2011;69:184-187.

6. Fragoso YD, Peres M. Prevalence of multiple sclerosis in city of Santos, SP. Rev Bras Epidemiol 2007;10:479-482.

7. Gama PD, Machado LM, Livramento JA, et al. Study of oligoclonal bands restricted to the cerebrospinal fluid in multiple sclerosis patients in the city of São Paulo. Arq Neuropsiquiatr 2009;67:1017-1022.

8. Correale J, Farez M. Association between parasite infection and immune responses in multiple sclerosis. Ann Neurol 2007; 61:97-108.

9. Carvalho L, Sun J, Kane C, et al. Review series on helminthes, immune modulation and the hygiene hypothesis: mechanisms underlying helminth modulation dendritic cell function. Immunology 2008;126:28-34

10. Correale J, Farez M, Razzitte G. Helminth infections associated with multiple sclerosis induce regulatory B cells. Ann Neurol 2008;64:187-199.
11. Bueno EC,VazAJ, Machado LR, et al.Specific Taenia crassiceps and Taenia solium antigenic peptides for neurocysticercosis immunodiagnosis using serum samples.J Clin Microbiol 2000;38:146-151.

12. Bueno EC, Snege M, VazAJ, et al.Serodiagnosis of human cysticercosis by using antigens from vesicular fluid of Taenia crassiceps cysticerci. Clin Diagn Lab Immunol 2001;8:1140-1144.

13. Espindula NM, Iha Al, Fernandes I, et al. Cysticercosis immunodiagnosis using 18- and 14-kilodalton proteins from Taenia crassiceps cysticercus antigens obtained by immunoaffinity chromatography. J Clin Microbiol 2005;43:3178-3184.

14. Ishida MMMI, Rubinsky-Elefant G, Ferreira AW, et al. Helminth antigens (Taenia solium, Taenia crassiceps, Toxocara canis, Schistosoma mansoni and Echinococcus granulosus) and crossreactivities in human infections and immunized animals. Acta Tropica 2003;89:73-84.

15. Vaz AJ, Nunes CM, Piazza RMF, et al. Immunoblot with cerebrospinal fluid from patients with neurocysticercosis using antigen from cysticerci of Taenia solium and Taenia crassiceps. Amer J Trop Med Hyg 1997; 57:354-357.

16. Espíndula NM, Vaz AJ, Pardini AX, et al. Excretory/secretory antigens (ES) from in-vitro cultures of Taenia crassiceps cysticerci, and use of an anti-ES monoclonal antibody for antigen detection in samples of cerebrospinal fluid from patients with neurocisticercosis. Ann Trop Med Parasitol 2002;96:361-368.

17. Towbin H, Staehelin T, Gordon J. Electrophoretic transfer of proteins from polyacrylamide gels to nitrocellulose sheets: procedure and some applications. Proc Nat Acad Sci USA 1979;76:4350-4352.

18. Sotgiu S, Angius A, Embry A, et al. Hygiene hypothesis: innate immunity, malaria and multiple sclerosis. Med Hypotheses 2008;70:819-825. 